\title{
Japanese Women's Perception of Changes in Marriage after Became Mualaf
}

\author{
Intan Hapsari ${ }^{1}$, Mohammaed Mossadeq Bahri ${ }^{2}$, Kurniawaty Iskandar ${ }^{3}$ \\ \{intanhapsari.ibs@gmail.com ${ }^{1}$, mossadeqbahri@gmail.com² ${ }^{2}$ daradwipa@yahoo.com ${ }^{3}$ \} \\ Universitas Indonesia, Indonesia ${ }^{1,2,3}$
}

\begin{abstract}
Islam is a minority religion in Japan. Now many Japanese people live in Indonesia to work or study. This made Japanese people interested in becoming mualaf. Mualaf means those who changed from their previous religion to become Muslims and became Muslims. The purpose of this study is to describe the influence of the reference group on the decision of Japanese women to become converts and Japanese woman's perception of changes in marriage after became mualaf. This type of research is a qualitative method with a phenomenological approach. This study collected data from interviews with Japanese women mualaf in Indonesia and library research that could help in this study. This study found that after Japanese women interacted with Indonesian Muslim, they wanted to study more about Islam and became mualaf. This study also found that after they became mualaf, they changed their view about marriage.
\end{abstract}

Keywords: Japanese Women, Marriage, Mualaf, Reference Group

\section{Introduction}

\subsection{Development of Islam in Japan}

Japan is known as a country of secularism. Japan as a secular country means seeing that morals and ethics are not based on religion. Therefore, religion tends to be considered not too important, even though the government is not allowed to take care of religious issues [1]. For most Japanese, religion is freedom. They do not want to be bound by one particular religious understanding.

Table 1. Number of adherents of religion in Japan

\begin{tabular}{lc}
\hline \multicolumn{1}{c}{ Religion } & The number of religious believers (people) \\
\hline Shinto & 86.166 .133 \\
Buddha & 85.333 .050 \\
Catholic and Protestant Christians & 1.921 .834 \\
Other religions & 7.743 .714 \\
\hline Total & 181.164 .731 \\
\hline \multicolumn{2}{c}{ Source: Statistics of Japan e-Stat is a portal site for Japanese Government Statistics [2] }
\end{tabular}

Based on table 1 above, total religious adherents in Japan from data issued and revised by the Ministry of Education of Japan recently are follows: Shinto followers are around 107 million people, Buddhism about 89 million people, Catholicism and Protestant followers are around 3 
million people and approximately 10 million people as other religions followers. When added together the total of all faiths in Japan will amount to 290 million people. Thus, most religions in Japan are Buddhism and Shintoism.

According to Fathil and Fathil [3] when compared to other religions, Islam is a minority religion in Japan. The Muslim community itself is very small at around $0.08 \%$ in proportion to the national population of Japan is more than 120 million, compared with Shinto and Buddhism whose followers constitute $83.9 \%$ and $71.4 \%$ of the national population of the country. Islam is a minority religion with even fewer followers than Christians (an estimated $2 \%$ of the total Japanese population who practice Christianity). Of these, the exact percentage of the Muslim community in Japan is uncertain for several reasons. The Japanese government does not keep records or statistics about the number of Muslims in this country. Unlike in other countries, religion is not considered an important demographic factor. This is considered a matter of individual choice and religious freedom. No survey has been conducted, or people have been asked to express their religious beliefs in their dealings with government agencies.

Table 2. The total Muslim population in Japan

\begin{tabular}{lc}
\hline Foreign Muslim Population & 91,744 \\
\hline Foreign Muslims married to Japanese & 10,055 \\
\hline The number of adult Muslims is over 20 years & 8,939 \\
\hline Japanese married to foreign Muslims (Muslim) & 8,939 \\
\hline Illegal Foreign Muslim Residents & 2,632 \\
\hline Other Japanese Muslims & 2,250 \\
\hline Estimated Total Muslim Population in Japan & 105,565 \\
\hline \multicolumn{2}{c}{ Source: Hirofumi [4]. }
\end{tabular}

Based on the estimation method above, at the end of 2011, there were 91,744 foreign Muslims, 8,939 couples (Japanese Muslims), and 2,632 Muslim "illegal residents". As for other Japanese Muslims, as explained in detail in the previous article, we calculate the ratio of the number of Japanese Muslims and the number of foreign Muslims visiting mosques in Japan. In the field survey so far, we have not seen as many as $10 \%$ of foreign Muslims gathered at the mosque. About 5\% of Muslims, 4,500 people are counted as "other Japanese Muslims". However, the Japanese who in this case have been counted as a "partner", mainly because it is possible to count double Japanese Muslim women, are 2, 250 people from "other Japanese Muslims". In total, number of Muslims in Japan is 105,565.

\subsection{Reference Group}

At present many Japanese people live in Indonesia to study and work. Indonesia ranks as the country with the largest Muslim population in the world. Japanese people living in Indonesia interact with groups of Muslims in Indonesia. This Muslim group became a reference group for Japanese people.

Table 3. Japanese Tourist Statistics Data Coming to Indonesia 2009-2017

\begin{tabular}{ll}
\hline Year & Amount \\
\hline 2009 & 488,320 \\
2010 & 416,151 \\
2011 & 423,113 \\
2012 & 463,486
\end{tabular}




\begin{tabular}{cc}
2013 & 497,399 \\
2014 & 505,175 \\
2015 & 528,606 \\
2016 & 545,392 \\
2017 & 573,310 \\
\hline Source: Number of Visits Tourist by Nationality $2000-2017$ (Statistics Indonesia).
\end{tabular}

Based on the table above shows that Japanese tourists visiting Indonesia increased from 2009 to 2017 by 84,990 people. In 2009, 488,320 Japanese tourists visiting Indonesia. In 2010 Japanese tourists who came to Indonesia decreased by 72,169 people. In 2011, Japanese tourists visiting Indonesia increased again to 423,113 inhabitants. Then in 2012, Japanese tourists coming to Indonesia increased to 463,386 people. In 2013, Japanese tourists to Indonesia were 497,399 people, in 2014 it increased to 505,175 people. Then Japanese tourists to Indonesia in 2015 increased to 528,606 people. In 2016 Japanese tourists increased to 545,392 people. Finally, in 2017 Japanese tourists visiting Indonesia became 573,310 inhabitants.

According to Merton [5], reference groups are, in principle, almost innumerable: any of the groups of which one is a member, and these are comparatively few, as well as groups of which one is a member, and these are, of course, legion, can become points of reference for shaping one's attitudes, evaluations, and behavior. From this statement, the reference group, in principle, is almost countless: any group in which one of its members is, and this is relatively small in number, also a group in which one is a member, and this, of course, troops, can be a reference for forming a person's attitude, evaluation and behavior.

The concept of "reference groups" has been used in several ways, but their usefulness can be maximized when signifying that groups of alleged perspectives are used by actors as a frame of reference in the organization of their perceptual fields. In other words, it is a person whose attitudes, behaviors, beliefs, opinions, preferences, and values are used by individuals as a basis for their judgment. One must not (or even aspire) members of the reference group to be influenced negatively or positively by their characteristics. Reference groups provide the benchmarks and contrast needed for comparison and evaluation of group and personal characteristics. Reference groups provide the benchmarks and contrast needed for comparison and evaluation of group and personal characteristics. Merton [5] hypothesized that individuals compare themselves with reference groups of people who occupy the desired social role of individuals. Defined thus, it becomes clear that all types of units can function as reference groups. Attention should not be limited to easily identified organized groups. Hearing to which a person can act consists of one person, a handful of people with whom he is in continuous contact, voluntary associations, or several broad categories of people - social classes, professions, ethnic groups, or several societies. The reference group is the audience, which consists of real or imaginary personifications, to whom certain values are included. This is an audience before someone trying to maintain or improve his position [6].

According to Merton and Rossi [7], the concept of reference groups opens up important new problems in sociology. Thus, while the field has long focused on how the group members (group members) shape attitudes and behaviors, it has ignored the problem of fact-centered orientation on this non-membership group, which is a particular concern of reference group theory. The authors especially criticized George Herbert Mead's theory of taking on other roles. This formulation is too narrow because Mead basically put forward the hypothesis that it is grouped in which individuals are members who produce a significant frame of reference for self-evaluation. The authors then cite the work of both sociologists (Charles H. Cooley, George Herbert Mead) and psychological (William James, Herbert H. Hyman, Muzafer Sherif, 
Theodore Newcomb) social psychologists in supporting their statement that subordinates or prospective group members would tend to assimilate sentiments and adjust to the authoritative strata or prestige values of certain groups. Such identification can function both for individuals (by facilitating adjustments) and for groups (by supporting their legitimacy). Other identifications with selected reference groups, however, lead to tension or conflict, such as when members of higher social classes identify with lower classes and thus appear disloyal to peer status [7].

More recently reference group theory has been articulated more explicitly. Various authors have reiterated Merton's theory as a formal theoretical proposition, such as Cochran and Beeghley [8], Bock, Beeghley, and Mixon [9]. In their view, the effect of reference groups on individual behavior and beliefs is motivated by five indicators that can be empirically verified. For convenience, Cochran and Beegley's official proposition is quoted in its entirety here:

The degree to which a group or collectivity functions as a reference group for an individual is a positive and additive function of (1) the degree of similarity between individual status attributes and other members; (2) the extent to which one's values and beliefs agree with the values of other members; (3) the level of clarity in-group values and beliefs; (4) the extent to which the individual is in ongoing interaction with other group members; and (5) the extent to which one defines group leaders as significant others [8].

As noted above, much research on reference groups makes membership in certain religious denominations a starting point. Cochran and Beeghley [8] have noted that " $[\mathrm{m}]$ any religious group consistently fulfills this criterion and therefore forms an important reference group for their dedicated members". I propose alternatives to the relatively limited application of standard reference group theory (for example, church members, gang members, sports teams, age groups, etc.) and would suggest moving to the consideration of macro-level groupings such as members of different national states. While it is clear that modern states consist of multidimensional constituencies, groupings, and status classes, there are compelling and empirical reasons used to argue that members of certain nation-states do share important characteristics with members of other reference groups from them.

Japanese people often interact with Muslims, they see how Muslim behavior. This made Japanese people interested in becoming converts. The word convert means those who change from their previous religion to Islam and become Muslims. In Islam, they are called converts. The Encyclopedia of Islam explains that the word mualaf comes from the Arabic AlMuallafa Qulübuhum which means people whose hearts are won or hearts that need softening.

Japanese people began to be interested in embracing Islam because of the teachings of Islam, which appreciate all of their followers, also, some of them reasoned that Islamic religion is also very compatible with personalities that have been embedded in them such as shame, independence, never giving up, loyalty, innovation, hard-working, respecting women and parents and frugal. All of that has been taught from an early age in Islam and Japanese society. Although many Islamic teachings are compatible with the personality of Japanese society in general, there is a different understanding after Japanese converts to convert to Islam, as well as an understanding of perceptions of marriage in Japan.

\subsection{Perception of Marriage in Japan}

The population in Japan is currently declining due to an increase in Japanese people who delay marriage and a decline in the number of married people. This can be seen in table 4 the number of annual marriages in Japan exceeded 1 million couples in the early 1970s, coupled 
with a marriage rate (per 1,000 population) that exceeded $10 \%$, indicating a real marriage boom. However, both the number of couples and the rate of marriage started to decline thereafter. They rose again in the late 1980s, but in recent years, they have generally declined. In 2017, 606,863 couples married, and the marriage rate was 4.9\%. The average age of first marriage was 31.1 for men and 29.4 for women in 2017. This is the same age for men and women as in the previous year. The average age of first marriage for men increased by 2.6 years, while women increased by 2.8 years over the past 20 years (in 1997: groom, 28.5; bride, 26.6).

Table 4. Average Age of First Marriage

\begin{tabular}{ccc}
\hline Year & Groom & Bride \\
\hline 1950 & 25.9 & 23.0 \\
1955 & 26.6 & 23.8 \\
1960 & 27.2 & 24.4 \\
1965 & 27.2 & 24.5 \\
1970 & 26.9 & 24.2 \\
1975 & 27.0 & 24.7 \\
1980 & 27.8 & 25.2 \\
1985 & 28.2 & 25.5 \\
1990 & 28.4 & 25.9 \\
1995 & 28.5 & 26.3 \\
2000 & 28.8 & 27.0 \\
2005 & 29.8 & 28.0 \\
2010 & 30.5 & 28.8 \\
2015 & 31.1 & 29.4 \\
2016 & 31.1 & 29.4 \\
$2017 *$ & 31.1 & 29.4 \\
\hline
\end{tabular}

Source: Ministry of Health, Labor and Welfare in the Statistical Handbook of Japan [2].

Whereas in table 4 there is an increase in the percentage of non-marriages for life, reaching $23.4 \%$ for men and $14.1 \%$ for women in 2015 , the highest percentage ever. Declining marriage rates, increasing marriage age and increasing unmarried life choices in recent years as described above are one of the explanations for declining birth rates.

Table 5. Proportion of Never Married at the Right Age of 50 years based on Gender ${ }^{1)}$

\begin{tabular}{ccc}
\hline Year & Groom & Bride \\
\hline 1950 & 1.5 & 1.4 \\
1960 & 1.3 & 1.9 \\
1970 & 1.7 & 3.3 \\
1980 & 2.6 & 4.5 \\
1990 & 5.6 & 4.3 \\
2000 & 12.6 & 5.8 \\
2005 & 16.0 & 7.3 \\
2010 & 20.1 & 10.6 \\
2015 & 23.4 & 14.1 \\
\hline 1)
\end{tabular}

${ }^{1)}$ The proportion is calculated as the average value of the proportion who are single at ages 45-49 and 50-54.

Source: Institute for Population and Social Security Research, Statistical Handbook of Japan [2]. 
Kawamura [10] states that the majority of unmarried Japanese young people report that they want to get married someday. Recent studies have shown that a large proportion of unmarried men and women report having not met a suitable partner as an excuse to remain single [11]. However, several factors are often incompatible with marriage, making marriage less attractive to some individuals. For example, increased participation of the female workforce as well as increased participation in higher education among women but the unchanging division of gender-based domestic work makes it difficult for Japanese married women to balance work and family [11].

The extension of an adult child living with parents is another factor often cited in the literature on later marriages and less in Japan. Unlike in the United States and certain parts of Europe, young men and women in Japan rarely leave their parents' homes before marriage unless their work or school is far from their home family. Among unmarried people who live separately from their parents, most live alone rather than living together. Because the regulation of premarital life of young adults is largely the result of geographical needs related to work or school, rather than their own values or resources, it is not surprising that the proportion of unmarried people living with parents has remained rather constant since the 1970s [11]. Because of this lack of change, the regulation of premarital life is unlikely to explain later and fewer marital trends in Japan. Not only is Japan's age at first marriage very high, around age 30, but later and fewer marital trends are also closely related to a decline in fertility. Unlike in many Western industrialized countries which have experienced a decline in marriage, cohabitation and childbearing in marriage are still relatively rare in Japan [12]. Therefore, delayed marriages greatly affect Japanese birth rates [13], which ultimately pushes the country to the lowest fertility.

Based on the assumptions described above, this research focused on the following problems: How does the reference group influence the decision of Japanese women to become converts? and how has the Japanese woman's perception of marriage changed after becoming a convert?

\section{Method}

\subsection{Types and Types of Research}

The research method is a scientific way to get data with specific goals and uses [14]. Research methods can be divided into several types, namely quantitative methods, qualitative methods, and mixed methods. This type of research is a qualitative method. Qualitative research is method to explore and understand the meaning by a number of individuals or groups of people ascribed to social or humanitarian problems [15]. Meanwhile, according to Bogdan and Taylor [16], qualitative methodology is a research procedure that produces descriptive data in the form of words written or spoken from people and behaviors that can be observed and this approach is directed at the background and individual holistically (whole). Qualitative methods have a more diverse approach to academic research than quantitative methods. Although the process is the same, qualitative procedures still rely on data in the form of text and images, have unique steps in the analysis of the data, and are sourced from different research strategies [15].

This research uses a phenomenological approach. Research phenomenology (phenomenological research) is a research design that comes from philosophy and psychology in which researchers describe the experience of human life on a phenomenon certain 
likely described by the participants. This design has a strong philosophical foundation and involves conducting interviews [17][18]. Researchers used a phenomenological approach to express the value of the family concept from the point of view of Japanese society and from the viewpoint of the Islamic religion through the life experience of Japanese converts.

\subsection{Data Sources}

The main data sources in qualitative research are words and actions, the rest is additional data such as documents and others [19]. The primary data of this study are in the form of interviews with researchers of Japanese converts in Indonesia related to the influence of reference groups on the decision of Japanese women to become converts and changes in the perception of Japanese women about marriage after becoming converts.

Criteria for Respondents:

a. Japanese woman;

b. Aged 20 and above;

c. Tokyo origin;

d. Have lived in Indonesia;

e. Become a convert at least 2 years.

When researchers look for sources, researchers get information from fellow researchers. They have Japanese converts who have lived or are living in Indonesia. Researchers communicate with informants through WhatsApp or Line. When the researchers got four speakers and they were willing to be interviewed, suddenly one of the speakers was not willing to be interviewed. However, researchers found one more informant who was willing to be interviewed. One of the interviewees also could not meet in person to interview with the researcher, so the researcher suggested interviewing through a voice call and the resource person was willing. When the writer wants to interview the informant, it is very difficult to find the right time because their schedules are very tight.

While secondary data in this study through literature review in the form of books, articles, journals and electronic media in the form of web links, and e-news which are helping in data for this research.

\subsection{Data Collection Techniques}

The steps of collecting data include efforts to limit research, collect information through observation and interviews, both structured and not, documentation, visual materials, and efforts to design a protocol for recording/recording information [15]. The primary data collection technique used is a depth interview technique. The interview is a meeting of two people to exchange information and ideas through questions and answers, so that meaning can be constructed in a particular topic [20]. Meanwhile according to Moleong [21]. An interview is a conversation with a specific purpose conducted by two parties, namely the interviewer (interviewer) who asks questions and interviewees (interviewees) who provide answers to these questions [21]. Stainback [22] revealed that with interviews, researchers will find out more deeply about participants in interpreting situations and phenomena that occur, where this cannot be found through observation. Researchers used in-depth interviews in order to find out the changes in the value of family roles through the perception of Japanese converts in Indonesia in detail.

When collecting data through interviews, the author will conduct unstructured and openended interviews designed to generate opinions from participants while recording them with 
audiotape, then transcribe Creswell [15]. In qualitative interviews (qualitative interviews). Researchers will conduct face-to-face interviews with participants. The idea behind qualitative research is to choose deliberately and planful (purposefully select) the participants and the location (document or visual material) of research that can help researchers understand the problem under study [15]. Phenomenology generally consists of three to ten participants [15]. Based on those things, the researcher intends to interview four Japanese converts who live in Indonesia because access is easier compared to converts who are in Japan.

When collecting data, the authors interviewed the interviewees through in-depth interviews using interview guidelines that had been made by previous authors. While secondary data collection techniques are used by collecting qualitative documents. The document is a record of events that have passed [23]. This document can be in the form of public documents (for example, newspapers, papers, office reports) or private documents (for example diaries, diaries, letters, e-mails) [15]. While gathering secondary data through the study of articles and journals, topics were chosen regarding the concept of reference groups and the concept of marriage in Islam and Japan.

\subsection{Data Analysis Techniques}

Bogdan [16] states that data analysis is the process of systematically searching and compiling data obtained from interviews, field notes, and other materials so that they can be easily understood, and their findings can be shared with others. The data analysis can be done with $g$ organizing da $t a$, translate it into the units, synthesize, organize into a pattern, choose what is important and what will be learned, and make inferences that can be told to others. The following are the analysis steps after collecting data, namely: collecting data, coding data, describing data, analyzing using concepts and theories, and summarizing data.

\section{Results and Discussion}

\subsection{Identity of Informants}

From the data collected, the similarities of the three informants are adult Japanese women aged 20 years and over, originally from Tokyo, who have lived in Indonesia for at least a year, and became a convert for at least one year. The cities where they live in Indonesia are different, some from Depok, Bogor, and Tangerang. Even so, the cities where they live are among the biggest in Indonesia. Their work also varies, there is a student, a private employee, and an employee at the embassy. The following is a description of the informants that have been collected.

\subsection{Effects of Reference Groups}

\subsubsection{Identification of Reference Group Models}

a. Peer group socialization

Mrs. YY (42) said that she decided to convert to Islam because of her ex-husband. Before marriage, she met her ex-husband in Indonesia. After that, they often met and finally decided to get married. Mrs. YY studied Islam and became a convert to marry her ex-Muslim husband. 
Whereas Ms. MN (23) said that what made him decide to become a convert was the Indonesian people he met when I first went to Indonesia. Ms. MN makes them a reference because it is touched by the helpful attitude inherent in Muslims or Indonesians in general. He also saw Indonesians as being more positive even though their welfare level might be lower than that of Japan. He also said that many Indonesians were more grateful.

\section{b. Media Socialization}

The second reference used as a reference is media socialization. one of them is print media such as books. Mrs. YY (42) said that he studied Islam from books such as the Qur'an, hadiths, etc. Mrs. YY learned that in Islam the religion must do good to people and according to him it can be understood because basically, humans must do good to others

Whereas Ms. MN (23) told that he learned almost all basic knowledge about Islam through books available on the internet, such as provided on the website http://www.islamjapan.com/pdf/book_islam_basics.pdf.

Ms. MN also said that specifically, Arisa Nur Maryam (convert Japan) that influence the decision to become converts because Arisa is the first to highlight the identity of her converts in social media. Ms. MN admires Arisa's courage because not many Japanese people have courage. Ms. MN sees Arisa from her social media which contains her daily life as a Muslim woman or gives references to Japanese people who consider Islam as a way of life, as well as recommending books or other media that are roughly useful for Japanese people who are considering Islam.

\section{c. Socialization of Religion}

The reference that is used as a reference is the socialization of religion, one of which is the Koran teacher, such as the story of Miss YY. Ms. YY also studied Islam from her teacher of prayer. Ms. YY said that among all the references, she liked the Koran teacher the most because she understood Islam better and could ask directly if there was an understanding that was not understood. For example, Mrs. YY was told that in Islam the religion should not consume pork. At first, Mrs. YY could not understand why the pig is unclean, and after having asked her religion teacher, Mrs. YY finally understood.

\subsection{Changes in Marriage Perception in Japanese Converts}

\subsubsection{Changes in Perception Regarding Marriage Expectations}

According to Mrs. YY (42), before entering Islam, she had the intention to marry because she wanted to have children. She wants to get married at the age of 16 years because she wants to have her own children at a young age. Mrs. YY also said that her criteria for a desired partner is a man who can draw a family and be responsible for his family.

Meanwhile, according to Ms. MN (23), after converting to Islam she wanted to marry a Muslim man. She also said that she wanted to get married as soon as possible, if possible, because by marrying a Muslim, she thinks it will be easier to learn the religion of Islam in daily life from the partner. According to Ms. MN, her ideal partner is a man who carry out Islamic obligations, not consuming alcohol and not smoking, and before converting to Islam she did not those criteria. 


\subsubsection{Changes in Perception of Children}

Mrs. YY (42) said that before she converted to Islam, she wanted to have as many children as possible because she liked children. Mrs. YY said that after entering Islam there was no difference in his opinion. This happens because when Mrs. YY was 16 years old in 1993. At that time, the rate of having children in Japan was higher than in 2010 and above. Perception Mrs. YY also did not change after converting to Islam because her thought was similar to the concept in Islam. It is said that Islam encourage a person to have more children, since the more children someone has, is better because there will be more sustenance for him/her.

In the other hand, Ms. MN (23) said that until now he had not thought about whether she is going to have children or not. This is in line with the declining rates of having children in Japan. The perception of the concept of having children in contemporary Japan is still more influential than the concept of having children in Islam.

\subsubsection{Changes in Perception Regarding the Division of Roles in the Work and Domestic Sectors}

Mrs. YY said that before entering Islam, there were no plans on whether to become a housewife or work. After she married and converted to Islam, she worked. Whereas Ms. MN said that, after entering Islam she planned to work but not for full-time if she has children. The perception between the concept of working in contemporary Japan and the concept of being a housewife of Islam is equally influential.

\section{Conclusion}

Japanese women decide to convert to Islam because they are influenced by a reference group. Reference groups can influence a person's behavior, attitudes, and views even though they are not members of that group. They interacted with Muslim in Indonesia, they found that they are kind, and they want to follow their behavior, attitudes, and perception.

Also, there is a change in the perception of marriage after Japanese women become converts. They changed their perception of marriage after they learnt about Islam's concept of marriage. They build their perception from Japanese's concept of marriage to Islam's concept.

\section{References}

[1] A. M. Sari, "Sekularisme Jepang: Premis Umum Mengenai Eksistensi Religi," Universitas Airlangga, 2014.

[2] Statistical Handbook of Japan 2018, "Statistics Bureau Ministry of Internal Affairs and Communications Japan," Statistical Handbook of Japan 2018, 2018. [Online]. Available: https://www.stat.go.jp/english/data/handbook/index.html.

[3] F. Fathil and F. Fathil, "Islam in minority Muslim countries: A case study on Japan and Korea," World J. Islam. Hist. Civiliz., vol. 1, no. 2, pp. 130-141, 2011.

[4] Hi. Tanada, "Muslim Population in the World and Japan, 2011," Ningen kagaku kenkyu, pp. 2939, 2013.

[5] R. K. Merton, Social Theory and Social Structure. New York: The Free Press, 1949.

[6] M. H. FrouzanFar, S. Meimar, and F. Tagipour, "The Role of Reference Groups on Student's Cultural Values," Interdiscip. J. Contemp. Res. Bus., 2012.

[7] R. K. Merton and A. S. Rossi, "Contributions to theTheory of Reference Group Behavior," in 
Continuities in Social Research, R. K. Merton and P. F. Lazarsfeld, Eds. Free Press, 1957.

[8] J. K. Cochran and L. Beeghley, "The influence of religion on attitudes toward nonmarital sexuality: A preliminary assessment of reference group theory," J. Sci. Study Relig., pp. 45-62, 1991.

[9] E. W. Bock, L. Beeghley, and A. J. Mixon, "Religion, socioeconomic status, and sexual morality: An application of reference group theory," Sociol. Q., vol. 24, no. 4, pp. 545-559, 1983.

[10] S. Kawamura, "Marriage in Japan: attitudes, intentions, and perceived barriers." Bowling Green State University, 2011.

[11] J. M. Raymo, M. Iwasawa, and L. Bumpass, Cohabitation and first marriage in Japan. Citeseer, 2007.

[12] J. M. Raymo, M. Iwasawa, and L. Bumpass, "Cohabitation and family formation in Japan," Demography, vol. 46, no. 4, pp. 785-803, 2009.

[13] G. W. Jones, "Delayed marriage and very low fertility in Pacific Asia," Popul. Dev. Rev., vol. 33, no. 3, pp. 453-478, 2007.

[14] D. P. Sugiyono, "Statistika untuk Penelitian," Bandung Alf., 2017.

[15] J. W. Creswell, Research Design: Pendekatan Metode Kualitatif, Kuantitatif, dan Campuran. Yogyakarta: Pustaka Pelajar, 2016.

[16] R. Bogdan and S. J. Taylor, "Pengantar Metode Penelitian Kualitatif," Terjem. Ali Furchon. Surabaya Usaha Nas., 1992.

[17] A. Giorgi, The descriptive phenomenological method in psychology: A modified Husserlian approach. Duquesne University Press, 2009.

[18] C. Moustakas, Phenomenological research methods. Sage publications, 1994.

[19] J. Lofland, D. Snow, L. Anderson, and L. H. Lofland, "Analyzing Social Settings: A Guide to Qualitative Observation and Analysis (Belmont, CA: Wadsworth/Thomson Learning)." Inc, 2006.

[20] K. G. Esterberg, Qualitative methods in social research, no. 300.18 E8. 2002.

[21] L. J. Moleong, "Metodologi Penelitian Kualitatif (Edisi Revisi)," in PT. Remaja Rosda Karya, 2017.

[22] S. Stainback and W. Stainback, Understanding \& Conducting Qualitative Research. ERIC, 1988.

[23] Sugiyono, Educational Research Methods (Quantitative, Qualitative, and R\&D Approaches). Bandung: Alfabeta, 2017. 